\title{
New Thinking of Wealth Management Under Civil Code Implementation - Based on Family Risk Identification and Legal Protection
}

\author{
Dong Siwei \\ School of Accounting, Shandong Technology and Business University, Yantai, China \\ Email address: \\ 43041515@qq.com \\ To cite this article: \\ Dong Siwei. New Thinking of Wealth Management Under Civil Code Implementation - Based on Family Risk Identification and Legal \\ Protection. International Journal of Economics, Finance and Management Sciences. Vol. 9, No. 5, 2021, pp. $210-214$. \\ doi: 10.11648/j.ijefm.20210905.16
}

Received: September 28, 2021; Accepted: October 21, 2021; Published: October 29, 2021

\begin{abstract}
With the development of economy, the prosperity of the country, the increase of income and the prosperity of people's life, family wealth management has gradually become a part of life. Good household wealth management can not only maintain and increase wealth, but also avoid or reduce the risk of sudden wealth. In order to understand the impact of the estate administrator system on the inheritance of wealth, to eliminate the troubles of Chinese-style wealth inheritance and study the path of wealth inheritance. On May 28, 2020, the first new legal code of China was born -- the Civil Code. As a law most closely related to each individual, the draft Civil Code is the first draft law named after the code since the founding of the People's Republic of China. It is a basic standard of civil law. Based on the Civil Code, this paper considers the following three issues: the impact of the estate administrator system on the inheritance of wealth; How to support children's wealth skillfully under the new Civil Code; Marital debt system and household and enterprise debt segregation scheme. This paper introduces a new strategy of debt isolation to protect family wealth, and skillfully isolates debts through prudent use of guarantee, clever use of assets and financial assets, etc.
\end{abstract}

Keywords: Civil Code, Wealth Inheritance, Wealth, Household

\section{Introduction}

Civil Code is a basic standard of civil law. [1] The draft civil Code consists of seven parts, including general Provisions, real rights, contracts, personal rights, Marriage and family, inheritance, tort liability, and supplementary Provisions, with 1,260 articles and a total of more than 100,000 words, the most articles in any draft law since the founding of the People's Republic of China. The draft covers every aspect of people's lives, including the life, old age, illness, death, clothing, food, shelter and transportation of every individual. The production and operation of every enterprise and the business activities of every organization cannot be separated from its norms and protection. [2]

Article 965 Where a client, after receiving the services of a broker, takes advantage of the transaction opportunities or media services provided by the broker to bypass the broker and enter into a contract directly, it shall pay remuneration to the broker.
Article 359 When the term of the right to use residential construction land expires, it shall be automatically renewed. The payment or reduction of renewal fees shall be handled in accordance with the provisions of laws and administrative regulations.

The renewal of the right to use non-residential construction land upon expiration shall be handled in accordance with the provisions of law. If there is an agreement on the ownership of houses and other realties on the land, such agreement shall prevail; If there is no such agreement or the agreement is not clear, it shall be handled in accordance with the provisions of laws and administrative regulations. [3]

Based on the Civil Code, this paper considers the following three issues: the impact of the estate administrator system on the inheritance of wealth; How to support children's wealth skillfully under the new Civil Code; Marital debt system and household and enterprise debt segregation scheme. 


\section{Identification and Legal Protection of Family Wealth Risk Under Civil Code Practice}

\subsection{The Impact of the Estate Administrator System on Wealth Inheritance}

The first key point of the Succession of civil Code: Article 1127.

The estate shall be inherited in the following order:

First order: spouse, children, parents.

Second in order: siblings, grandparents, maternal grandparents.

Article 1129.

Widowed daughters-in-law and sons-in-law who have made the main maintenance obligation to their parents-in-law shall be regarded as heirs first in order. [4]

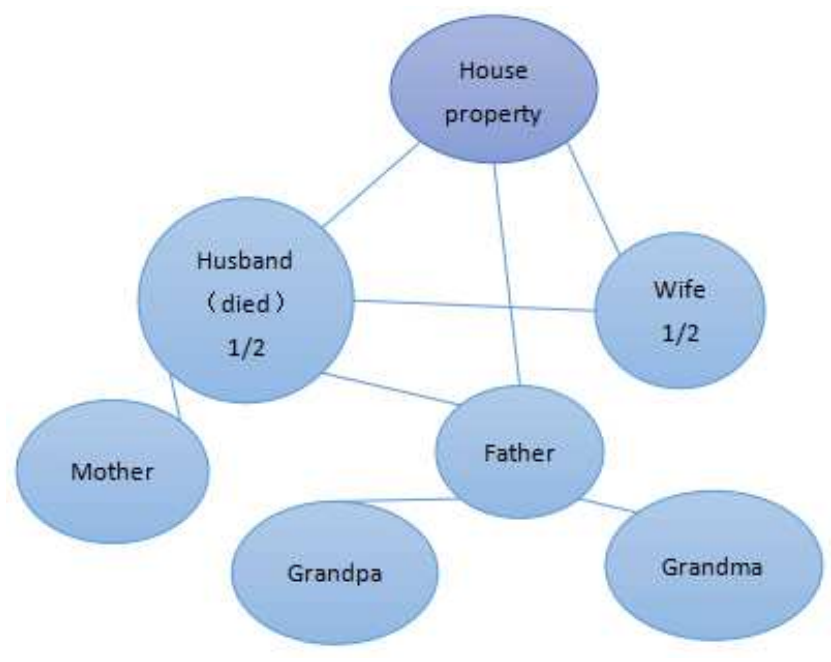

Figure 1. Transfer of husband and wife property.
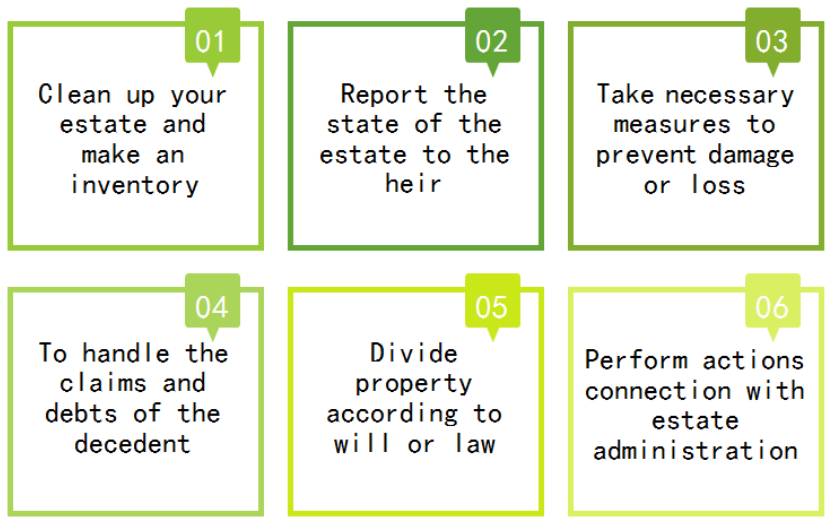

Figure 2. The administrator shall perform his duties.

The Second core point of the Succession of civil Code: Article 1145 of the Civil Code

After succession begins, the executor of the will shall be the administrator of the estate; If there is no testamentary executor, the successor shall elect an administrator without delay; If the successors are not elected, the successors shall jointly act as administrators of the estate; If there is no successor or both successors abandon succession, the civil affairs department or villagers' committee of the place where the decedent lived shall act as the administrator of the estate. [5]

Article 1149 of the Civil Code

The administrator of the estate may obtain remuneration in accordance with the law or the agreement.

\subsection{Chinese Style Wealth Inheritance Troubles}

\subsubsection{Losing a Couple's Property to Someone Else}

In the inheritance of a couple s joint property, the parents in the first line of succession will be extended to parents-in-law. Property passes to collateral blood in succession. [6]

\subsubsection{Ancestral Death Certificates Are Hard to Find}

Children are expected to inherit their parents' property and prepare a death certificate for their grandparents.

\subsubsection{Asymmetric Property Information}

Inheritable property should be provided by the heir. In Chinese family relationship, children often do not have the information of their parents' property.

\subsubsection{Uncircumvented Right of Inheritance Notarization}

The successors must get the notary office of the right of succession notarization or court judgment can handle the transfer of property rights.

\subsection{The Path of Wealth Transmission}

There will be three methods of wealth transmission first, Make a will. Second, Inheritance. Third, Marital property agreement. [7-8]

\subsection{How to Support Children's Wealth Skillfully Under the New Civil Code}

It's in the civil code that marital legal property system. Article 1062. During the duration of their marriage, the following property acquired shall be the joint property of the couple [9]:

(1) wages, bonuses and other remuneration for personal services;

(2) income from production, operation and investment;

(3) income from intellectual property rights;

(4) inherited or donated property, except those provided for in item 3 of Article 1063 of this.

Article 1063.

(1) the pre-marital property of one party;

(2) compensation or compensation obtained by one party for personal injury;

(3) property belonging to only one party as determined in a will or contract of gift;

(4) articles for daily use used by one party;

\subsection{Case Study}

Parents give a house, change the family name after marriage.

Daughter gets married, parents send daughter a small 
two-bedroom house, the house is written in daughter's name.

Two years later, a family of three want to sell the small house to change to a bigger one, do you agree? What has changed about the house?

Mr. Li: Honey, do you think your daughter can change to a bigger house?

Mrs. Lee: You're silly! If we change the house and have a joint name, the house will no longer belong to our daughter!

\subsubsection{The Tools Are Available to Address This Risk Problem}

(1) Signature of property. Newly purchased property, property ownership certificate can only write daughter's name.

(2) Open a separate account. Parents gift fund bank off account, and remarks designated gift, and avoid marriage and marriage property confusion.

\subsubsection{Three Tips for Supporting Your Children's Wealth}

\section{(i). Conditional Reverse Mortgage: Civil Code: Conditional Mortgages Can Be Frozen}

Article 406. During the mortgage period, the mortgagor may transfer the mortgaged property. If the parties agree otherwise, such agreement shall prevail. Where the mortgaged property is transferred, the mortgage right shall not be affected.

If the mortgagor transfers the mortgaged property, he shall timely notify the mortgagee. If the mortgagee is able to prove that the transfer of the mortgaged property may damage the mortgage right, he may request the mortgagor to pay off the debt or deposit the proceeds of the transfer to the mortgagee in advance. The part of the transfer price exceeding the amount of the obligatory right shall be owned by the mortgagor, and the short part shall be paid off by the debtor.

\section{(ii). Set Residency: New to Civil Code: Right of Residence}

Article 366. A person with the right of residence shall, in accordance with the contract, enjoy the usufructuary right of possession or use of another person's residence to meet the needs of living and living.

Article 368. The right of habitation shall be established free of charge, except as otherwise agreed by the parties concerned. Whoever establishes the right of residence shall apply to the registration organ for registration of the right of residence. The right of residence shall be established at the time of registration.

\section{(iii). Borrow the Policy Structure Wisely}

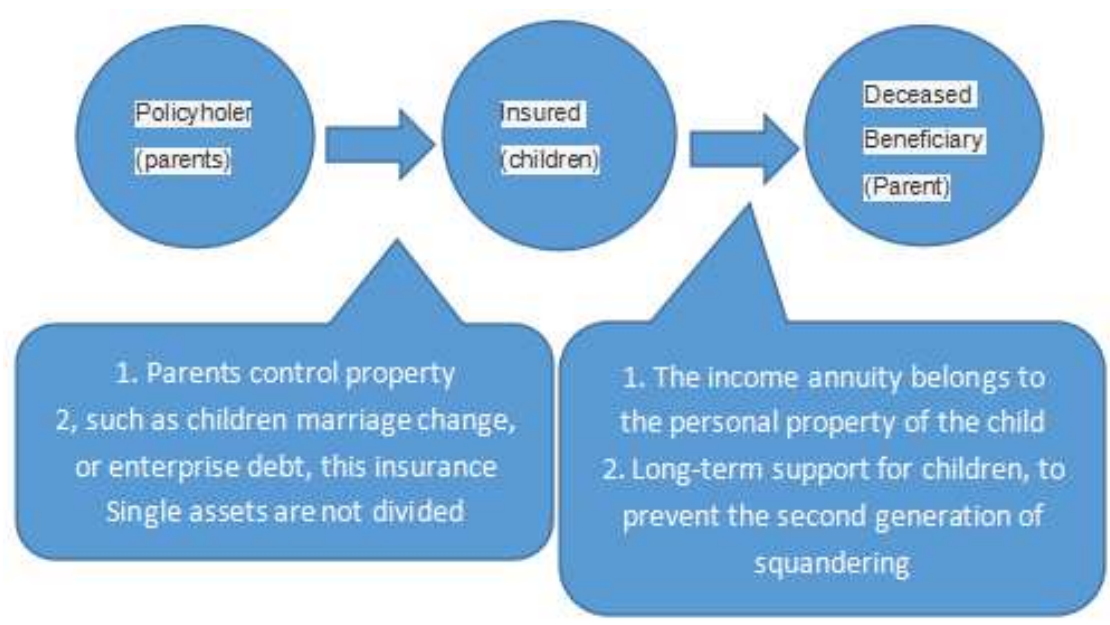

Figure 3. The policy framework $[10,11]$.

\subsection{New Rules on Joint Debt Between Husband and Wife and Plan on Debt Isolation Between Family and Enterprise}

\subsubsection{New to Civil Code: Recognition of Marital Joint Debt}

On the afternoon of May 28, 2020, the third session of the 13th National People's Congress voted to adopt the Civil Code of the People's Republic of China.

Article 1,064

The debts jointly signed by both husband and wife or later ratified by one of the husband and wife, as well as the debts incurred by one of the husband and wife in his or her own name to meet the daily needs of the family during the term of the marital relationship, shall belong to the debts jointly incurred by the husband and wife.
The debts incurred by one party of the husband and wife in his or her own name during the period of marriage in excess of the daily needs of the family shall not be classified as joint debts of the husband and wife; However, unless the creditor can prove that the debt is used for the husband and wife's joint life, joint production and business operation, or based on the joint intention of both husband and wife. [12]

\subsubsection{Standards for the Recognition of Marital Joint Debt in the Civil Code}

(1) Joint debt is signed by both husband and wife;

(2) One party later ratifies the debt as joint debt;

(3) One party is in debt for the daily life of the family;

(4) One party is in debt beyond the needs of daily life, and the creditor shall provide proof. Used for family life or production and operation. 


\subsubsection{The Impact of the New Rules on Marital Debt}

(1) The risk of large external loans will increase;

(2) There will be people using the new rules to avoid debt;

(3) Large financial institutions fortification in advance, binding joint husband and wife deb.

\subsubsection{Case Study: Failed to Go Public and Lost All Your Money}

In 1998, a company from Anhui registered a breeding enterprise.

In 2009, the company started to go public.

In 2011, the company borrowed 300 million yuan from the bank, which was jointly and severally guaranteed by $\mathrm{Mr}$. Zhang and his wife.

In 2012, the company withdrew its listing application due to the outbreak of avian flu.

In 2014, banks withdrew loans and suppliers called for debts, causing a series of risks.

In 2016, the company was insolvent with debts of 1.1 billion yuan and assets of 600 million yuan, and applied for bankruptcy.

In 2013, Zhang transferred his three properties to his 15 -year-old son.

Does Zhang transfer to the son's name of the three properties need to pay debts?

Article 74 of Contract Law says: Where the obligor waived its creditor's right that was due or assigned its property without compensation, thereby harming the obligee, the obligee may petition the people's court to cancel the obligor's act.

Article 75 of Contract Law says: Cancellation right shall be exercised within one year from the date when the obligee knew or should have known the cause for cancellation. Where the cancellation right is not exercised within five years commencing from the date of occurrence of the obligor's act, such cancellation right shall be extinguished.

This results that enterprise bankruptcy, all family assets are frozen, sealed up and auctioned and Zhang's son cannot study abroad for economic reasons. [13]

\subsubsection{Debt Isolation Strategy}

Debt isolation strategy 1: Use collateral sparingly

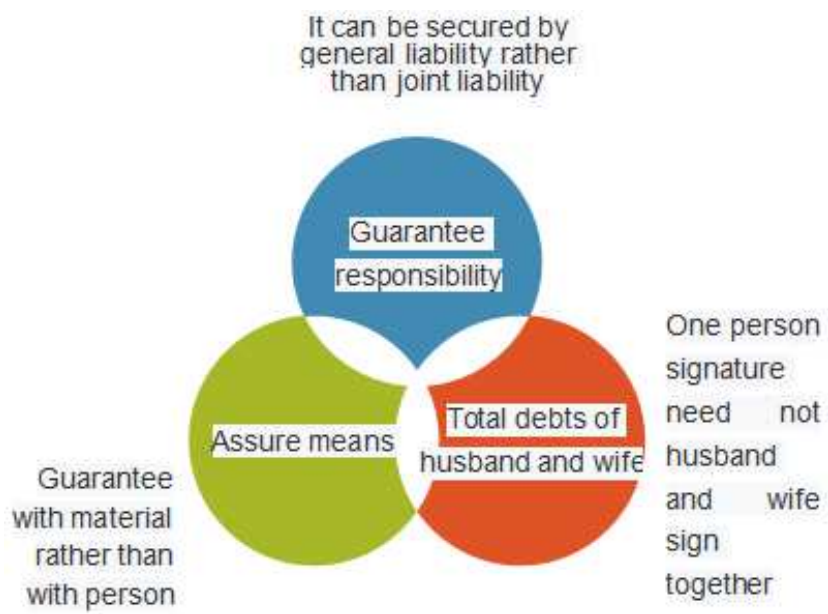

Figure 4. Guarantee policy [14].

Debt isolation strategy 2: smart use of assets held

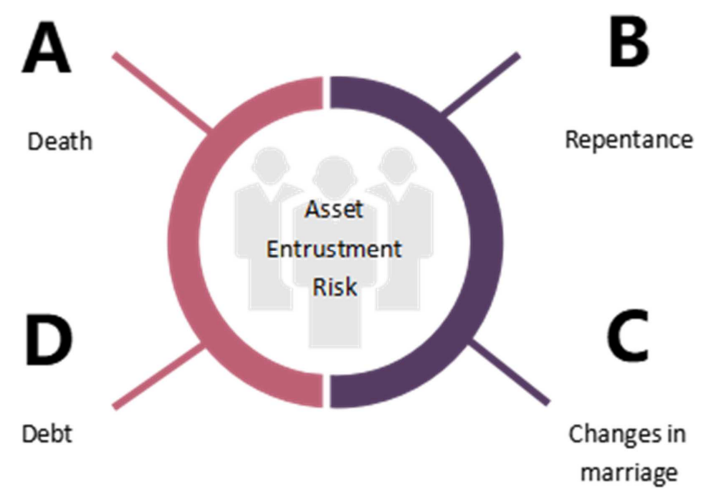

Figure 5. Asset entrustment risk.

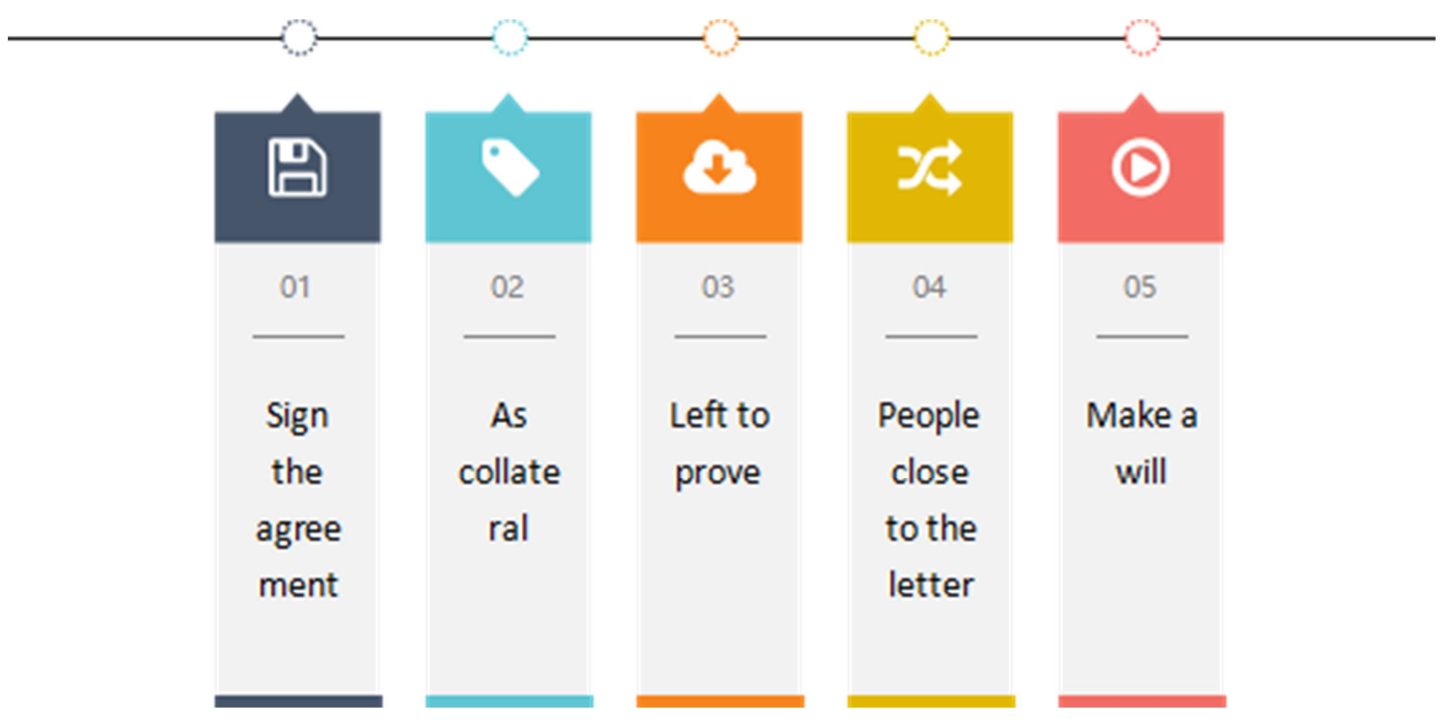

Figure 6. Five-step method.

Debt isolation strategy three: financial asset holding 


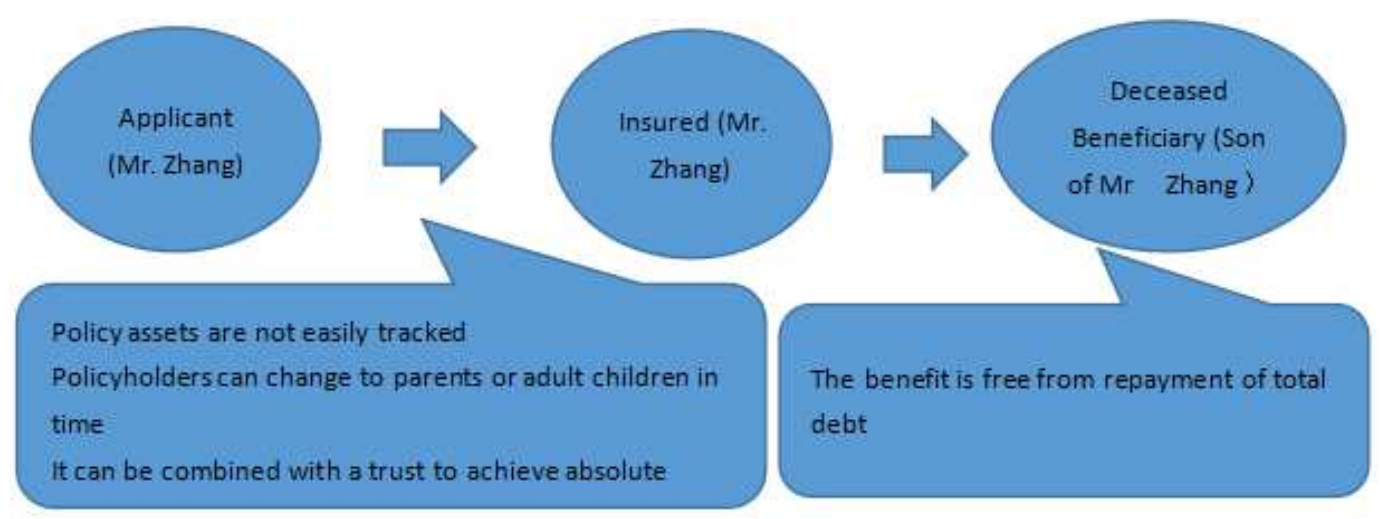

Figure 7. Financial asset entrustment [15].

\section{Conclusion}

Under the practical revision of the civil Code, we should have a new thinking of wealth management and refer to the seventh part of the draft civil Code to protect our lives and standardize the operation of enterprises. The Civil Code is an encyclopedia of social life. After the revision, we can know how to support the wealth of children by understanding the influence of the estate administrator system on the inheritance of wealth, and do a good job in wealth management through the husband and wife bond system and the family-enterprise debt separation scheme to prevent the occurrence of risks. Under the new civil code, this paper gives the skills to support children's wealth, such as property signature, separate account opening and other tools, conditional reverse mortgage, setting the right of residence, clever borrowing policy structure. In terms of the new rules on joint debt of husband and wife and holiday debt isolation, debt isolation strategies can be adopted, such as prudent use of guarantee, clever use of asset entrustment, financial asset entrustment and other methods to protect family property.

\section{References}

[1] Wang Geya, Civil Code, Succession: System supplement and Standard Refinement, J. Seeking Truth, 2020.

[2] Zhao Huihui, "New Rules on Wealth" in Civil Code, J. Modern Commercial Banking, 2020.

[3] Zhai Jiguang, The Innovation of Civil Code Succession and its Impact on the Inheritance of High Net Worth Individuals, J. China National Exhibition, 2020.

[4] Wang Baoshi, Study on the Application of Civil Code Estate Administrator System, J. Law and Economy, 2020.
[5] Zhang Jinhui, How to Make Good Use of "Autonomy of Will" to Preserve Wealth? -- Paying Attention to the Revision of the Marriage and Family Sections and Inheritance Sections of the Civil Code, J. China Family Business Review, 2020.

[6] Chen Danni, My Understanding of Private Wealth Management and Inheritance in China, J. Journal of Regional Financial Research, 2013.

[7] Li Yanshuang, A Multi-Case Study on the Formation Mechanism and Inheritance Path of Entrepreneurial Spirit, J. Scientific Decision Making, 2020.

[8] Zhou Yanli, "Research on the Application of Insurance in Wealth Management,” J. Insurance Studies, 2019.

[9] Zhang Juan, Insurance Demand Analysis of Chinese High Net Worth Population, J. Modern Business, 2016.

[10] Cai Yanhui, "Manage the Life Cycle of Your Family's Wealth", J. Economy, 2020.

[11] Sun Huixian, ""Insurance + Trust" Wealth Management Service -- Discussion on the Development of China's Insurance Trust Industry,” J. Shanghai Insurance Monthly, 2020.

[12] Li Xiaofei, Chen Fen, "Research on Family Wealth Management in Insurance Industry under the Background of Blockchain Technology,” J. Social Sciences in Guangxi, 2021.

[13] Ge Lianying, Lei Jie, Research on Insurance Trust Fusion Model of Wealth Management Business Model of Insurance Company, J. China Circulation Economy, 2020.

[14] Ye Taobao, Consensual Determination of "Joint Debt and Joint Signing Rule" of Conjugal Debt in Civil Code Era, J. Research on Rule of Law, 2020.

[15] Li Bingbing. The Opportunity and Thinking of Lawyers to undertake Civil and Commercial Cases from the Perspective of Civil Code -- Taking the System of Estate Administrator as an Example, J. Legality Vision, 2020. 